\title{
Thermal cycle of SI engine modeling with initial swirl proces into consideration
}

\begin{abstract}
Results of numerical modelling the initial charge swirl in piston engine cylinder and the influence of swirl profile on engine thermal cycle parameters have been presented in the paper. The shape of initial swirl profile of modelled engine was determined on the basis of the experimental researches. It was taken into consideration because the proper level of turbulence before the initiation of combustion is very important for engine work. The research was conducted using KIVA-3V software.
\end{abstract}

Key words: internal combustion engine, modelling, swirl, turbulence

\section{Modelowanie obiegu cieplnego silnika ZI z uwzględnieniem procesu wstępnego zawirowania}

\author{
Przedstawiono wyniki modelowania obiegu silnika ZI ze szczególnym uwzględnieniem procesu wstepnego zawirowania. \\ Modelowanie przeprowadzono w programie KIVA-3V. Modelowanie obiegu cieplnego silnika wykazało istotny wptyw \\ przyjętego wskaźnika zawirowania oraz profilu wstępnego zawirowania na przebieg zmian ciśnienia i temperatury w \\ cylindrze silnika.
}

Słowa kluczowe: silnik tłokowy, modelowanie, zawirowanie, turbulencja

\section{Introduction}

From the beginning of piston engine existence the influence of charge motion in the cylinder on its work has been observed. The influence of workspace geometry of cylinder on flow field turbulence in cylinder of piston engine has had significant influence on creation of new combustion conception in engines: lean mixture, heterogeneous mixtures and construction of high speed compression ignition engines. For a long time researches on the influence of inlet manifold shape and charge compression on turbulence generation (Lancaster, 1976; Nagayama, 1977; Matsushita, 1985; Heywood, 1988) has been performed. Witze and Hall have investigated the influence of flow charge velocity before ignition on combustion process quality. It has been proved, that there is significant impact of turbulence intensity of charge before ignition on mixture combustion speed [5]. The increase of turbulence intensity causes the increase in the combustion speed. Lower non-repeatability of flow field in subsequent cycles has been observed in engines with charge swirl in cylinder. In consequence it leads to lower unrepeatability of engine thermal cycles. This is particularly important for engine fuelled with lean mixture. Combustion process in these engines is characterised by low combustion speed and the thermal cycle of those engines is characterised by large non-repeatability of subsequent cycles. Charge swirl can make significant improvement in engine parameters.

One of the fundamental problems in combustion engines domain, which has been researched from many years, is non-repeatability of work cycles. In 1966 Patterson [4] observed non-repeatability of cycles on the basis of pressure variation. Whitelaw and $\mathrm{Xu}[8]$ researched influence of charge swirl on non-repeatability of engine work cycles. Influence of velocity fluctuation on engine work cycles non-

\section{Wstęp}

Już od początku istnienia silnika tłokowego zauważono wpływ ruchu ładunku w cylindrze na jego pracę. Określanie wpływu geometrii przestrzeni roboczej silnika na turbulencję pola przepływu w cylindrze silnika tłokowego miało znaczący udział w tworzeniu nowych koncepcji spalania w silniku: spalanie mieszanek ubogich, mieszanek uwarstwionych oraz w konstrukcji szybkoobrotowych silników wysokoprężnych. Od dawna badano wpływ kształtu układu dolotowego oraz sprężania ładunku na generację turbulencji (Lancaster, 1976; Nagayama, 1977; Matsushita, 1985; Heywood, 1988). Witze i Hall badali wpływ prędkości przepływu ładunku przed zapłonem, na jakość procesu spalania. Udowodniono, że zachodzi istotny wpływ intensywności turbulencji ładunku przed zapłonem na szybkość spalania mieszanki [5]. Dowiedziono, że zwiększenie intensywności turbulencji powoduje wzrost prędkości spalania. W silnikach, w których występuje zawirowanie ładunku w cylindrze zaobserwowano mniejszą niepowtarzalność prędkości w kolejnych cyklach, co w konsekwencji prowadzi do mniejszej niepowtarzalności obiegu cieplnego silnika. Jest to szczególnie istotne dla silników spalających mieszanki ubogie. Proces spalania w tych silnikach charakteryzuje się małą prędkością spalania, a obieg takiego silnika dużą niepowtarzalnością pracy w kolejnych cyklach. Zawirowanie ładunku może w znacznym stopniu poprawić wskaźniki pracy takich silników. Jednym z fundamentalnych zagadnień w dziedzinie silników spalinowych, które badane jest od wielu lat, jest niepowtarzalność cykli pracy. Już w 1966 roku Patterson [4] obserwował niepowtarzalność cykli na podstawie obserwacji zmian ciśnienia. Whitelaw i Xu [8] badali wpływ zawirowania ładunku na niepowtarzalność cykli pracy silnika. Stwierdzono, że fluktuacja prędkości ma znaczący wpływ na niepowtarzalność 
repeatability has been found. Charge swirl contributes to the increase of flame kernel shape repeatability [6]. Introducing the charge swirl has caused the increase of in cylinder pressure and combustion speed of $10-16 \%$. For engines without charge swirl the turbulence has been described as isotropic and homogeneous. For engines with charge swirl the strong anisotropic and non-homogenous turbulence have been observed. Heywood and Pischinger have affirmed that the optimal charge swirl velocity near spark plug should be in the range of $3-5 \mathrm{~m} / \mathrm{s}$ because of heat losses and flame kernel development. The higher charge flow velocities cause the break off glow phase of discharge on spark plug. Research on engineless test bed is one of way of flow processes in engine cylinder analysis. This test bed is a physical model of engine intake process. The numerical research into engineless test bed allow investigation of inlet manifold properties and the influence of inlet manifold shape on charge swirl rate at the end of compression stroke. This is typical method, which is commonly use to comparative investigations. Vane anemometer is most frequently used as a metering device of global swirl in cylinder.

\section{Initial swirl description}

A lot of data from real engine must be known in order to model the engine thermal cycle in KIVA-3V. This allows to gets results similar to real. One of these parameters is the one describing initial swirl. For engine modelling one has to know not only the swirl index (ratio) of fresh charge in the test engine, but also the profile of initial swirl at the beginning of computation.

For modelled engine the above mentioned physical model of cylinder filling during the intake stroke has been made. The initial swirl profile has been determined using the hot-wire anemometer. The same test bed has been used to determine the global initial swirl for BDC (Fig. 1).

The aim of measurements was to describe the swirl velocity variation character. In order to model the swirl in KIVA-3V software, not only information of swirl index, but also information on swirl velocity profile are required. Distribution of measurements points in analysed plane has been presented in Fig. 1.

Measurement was conducted in the same conditions as measurement of swirl with the use of vane anemometer. The aim of hot-wire anemometric measurement was to determine the fresh charge swirl velocity profile at the end of intake stroke. The measurements ware conducted in the same conditions like with vane anemometer, with the complete inlet manifold and fully open throttle. The 12 curves describing swirl profile in the plane perpendicular to cylinder cykli pracy silnika. Zawirowanie ładunku przyczynia się do większej powtarzalności kształtu jądra płomienia [6]. Wprowadzenie zawirowania spowodowało zwiększenie ciśnienia w cylindrze oraz zwiększyło prędkość spalania o $10-16 \%$. Dla cylindra bez zawirowania ładunku, turbulencję określono jako izotropową i homogeniczną, a w cylindrze, w którym występuje zawirowanie ładunku stwierdzono silną anizotropowość i niehomogeniczność turbulencji przepływu. Heywood i Pischinger stwierdzili, że optymalne prędkości zawirowania ładunku w okolicy świecy zapłonowej powinny być w zakresie $3-5 \mathrm{~m} / \mathrm{s}$, ze względu na straty ciepła elektrod świecowych oraz ze względu na rozwój jądra płomienia. Większe prędkości przepływu ładunku mogą spowodować zerwanie jarzeniowej części wyładowania iskrowego na świecy zapłonowej.

Jednym ze sposobów badania procesów przepływowych zachodzących w cylindrze silnika tłokowego są badania na tak zwanym stanowisku bezsilnikowym. Takie stanowisko badawcze stanowi fizyczny model procesu napełniania silnika. Badania modelowe na stanowisku bezsilnikowym wykorzystywane są do poznawania własności przepływowych układu dolotowego oraz wpływu układu dolotowego na stopień zawirowania świeżego ładunku w cylindrze w końcowej fazie suwu napełniania. Jest to metoda typowa i chętnie wykorzystywana do badań porównawczych. Najczęściej jest wykorzystywany anemometr wiatraczkowy, jako miernik globalnego zawirowania w cylindrze.

\section{Opis wstępnego zawirowania}

Modelując obieg cieplny silnika tłokowego, w programie KIVA 3V, musimy mieć duży zasób informacji pochodzących z rzeczywistego silnika, aby móc uzyskać wyniki jak najbardziej zbliżone do rzeczywistości. Jednymi z tych informacji są parametry opisujące wstępne zawirowanie. Modelując obieg silnika musimy nie tylko znać wskaźnik zawirowania świeżego ładunku dla danego silnika, ale także znać profil tego wstępnego zawirowania dla początku obliczeń.

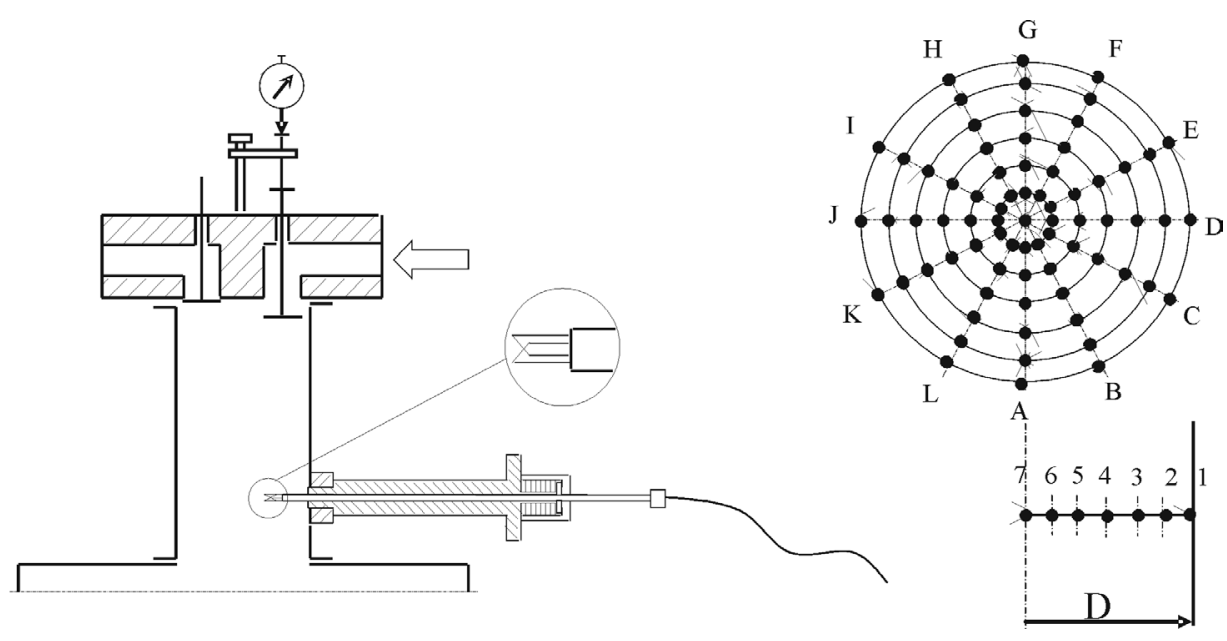

Fig. 1. Mounting system of thermoanemometer probe in the cylinder of the physical model and measurement points distribution

Rys. 1. Schemat sposobu montowania sondy termoanemometrycznej w cylindrze stanowiska modelowego oraz rozklad punktów pomiarowych 
axis were the result of measurement. The characteristic feature of obtained swirl profiles was the velocity maximum in 10-20 mm distance form cylinder wall. It is probably caused by the boundary layer effect.

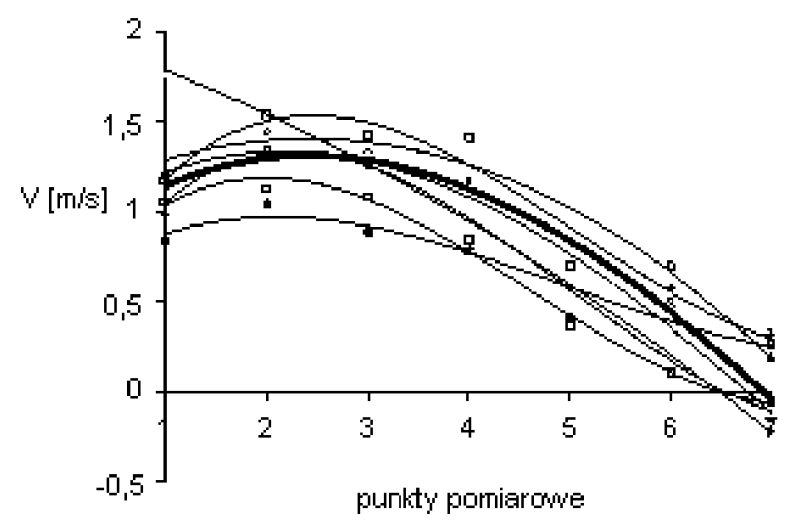

Fig. 2. Profile of swirl velocity

Rys. 2. Profil prędkości zawirowania w silniku badawczym

Figure 2 shows series of curves, which represent charge swirl profile in the investigated engine. The curve describing the swirl profile has been shown as a background of curves presenting the swirl profiles obtained from experimental researches.

Courses of tangential velocity changes show that the swirl do not has the character of rigid body. The centre of swirl do not overlap with the centre of cylinder. The swirl model used in KIVA software does not allow to introduce the swirl eccentricity. The value obtained from vane anemometer researches has been taken to describe the swirl index. The results show, that in each of the investigated radius (A-L), there was different swirl profile. In KIVA the swirl model assumes only one velocity swirl profile for whole plane where initial swirl is characterized. For that reason the mean distribution of swirl velocity has been described. Series of simulation in KIVA software with different values of $\alpha$ parameter has been conducted. The 2.7 was chosen as the most suitable value of $\alpha$ parameter for this engine. It has been selected on the basis of comparison of the modelling and research results.

\section{Swirl model}

The charge motion around cylinder axis is called the charge swirl. There are several models describing the charge swirl. The simplest model of this phenomenon is based on the swirl profile description. The charge is considered as a rotating rigid body. Such assumption is not in close relation with reality as the turbulent wall layer existing near the cylinder wall disturbs the swirl profile. The wall layer influence results in the decrease of swirl near the wall.

The model assumes that after aspirating process, the fresh charge in cylinder rotates like an undeformable rigid body (cylinder) of diameter equal $\mathrm{D}$ and mass equal $\mathrm{m}$. The CONCHAS model presents different approach to charge swirl description. A trapezium-like swirl velocity profile has been assumed. This model is characterized by zero velocity
Dla modelowanego silnika wykonano wspomniany model fizyczny procesu napełniania cylindra. Wykorzystując metodę termoanemometryczną pomiaru prędkości, wyznaczono profil początkowy wstępnego zawirowania. $\mathrm{Na}$ tym samym stanowisku bezsilnikowym dokonano pomiaru globalnego zawirowania początkowego dla położenia tłoka w WZP (rys. 1).

Pomiary miały na celu określenie charakteru zmian prędkości zawirowania. Modelowanie zawirowania programem KIVA wymaga określenia nie tylko stopnia zawirowania, ale także profilu prędkości zawirowania. Rozkład punktów pomiarowych w płaszczyźnie pomiarowej przedstawiono na rys. 1.

Pomiary przeprowadzono w takich samych warunkach jak pomiar zawirowania ładunku anemometrem wiatraczkowym.

Celem pomiarów termoanemometrycznych było określenie profilu prędkości zawirowania świeżego ładunku w końcowej fazie suwu napełniania. Badania prowadzone były podobnie jak przy pomiarze zawirowania anemometrem wiatraczkowym, dla kompletnego układu dolotowego z maksymalnym otwarciem przepustnicy. $\mathrm{W}$ wyniku pomiarów uzyskano 12 krzywych opisujących profil zawirowania w płaszczyźnie prostopadłej do osi cylindra. Cechą charakterystyczną uzyskanych profilii prędkości zawirowania jest osiąganie maksimum prędkości w odległości 10-20 mm od ścianki cylindra. Jest to spowodowane oddziaływaniem warstwy przyściennej.

Na rysunku 2 przedstawiono kilka krzywych obrazujących profil zawirowania ładunku w cylindrze badawczego silnika. Na tle krzywych obrazujących profil zawirowania uzyskanych z pomiarów przedstawiono przyjętą krzywą opisującą profil zawirowania w modelu.

Z przedstawionych przebiegów zmian prędkości obwodowej widać, że występujące zawirowanie nie ma charakteru ciała sztywnego. Środek zawirowania nie pokrywa się ze środkiem cylindra. Model zawirowania użyty w programie KIVA nie pozwala wprowadzić mimoosiowości zawirowania, dlatego do opisu wskaźnika zawirowania przyjęto wartość uzyskaną z pomiarów anemometrem wiatraczkowym. Wyniki pomiarów pokazały, że w każdym z badanych promieni (A-L) występował odmienny profil zawirowania. W programie KIVA model zawirowania przyjmuje jeden profil prędkości zawirowania dla całej płaszczyzny, w której określa się wstępne zawirowanie. Z tego względu wyznaczono średni rozkład prędkości zawirowania w płaszczyźnie pomiarowej. Przeprowadzono kilka symulacji komputerowych programem KIVA z różnymi wartościami parametru $\alpha$ określającego profil prędkości. Na podstawie porównania wyników modelowania i pomiaru określono parametr $\alpha=$ 2,7 jako najlepiej oddający charakter zmian prędkości zawirowania w badanym silniku.

\section{Model zawirowania}

Ruch ładunku wokół osi cylindra nazywany jest zawirowaniem ładunku. Istnieje kilka modeli opisujących zawirowanie świeżego ładunku. Najprostszym modelem tego zjawiska jest opis profilu zawirowania, w którym ładunek 
in the cylinder axis and on cylinder wall. It is an extension of the model describing swirl as a rotational movement of rigid body. The presented charge swirl models have been used in the CONCHAS 2D combustion chamber model. The simplified influence of wall layer is taken into consideration in the trapezium-like swirl profile model. It has been proved by means of experimental research that Bessel function is the most precise one to describe the initial swirl profile in piston engine cylinder. Such swirl description is used in KIVA-3V. It is a swirl model, which allows to modify the swirl velocity profile within specific limits. The swirl profile for rigid body with maximal velocity on the cylinder wall $(\alpha=0.0)$, arc shaped profile with zero velocity on the cylinder wall $(\alpha=3.83)$ and flow profile of shape most similar to real one $(\alpha=3.11)$ can be obtained.

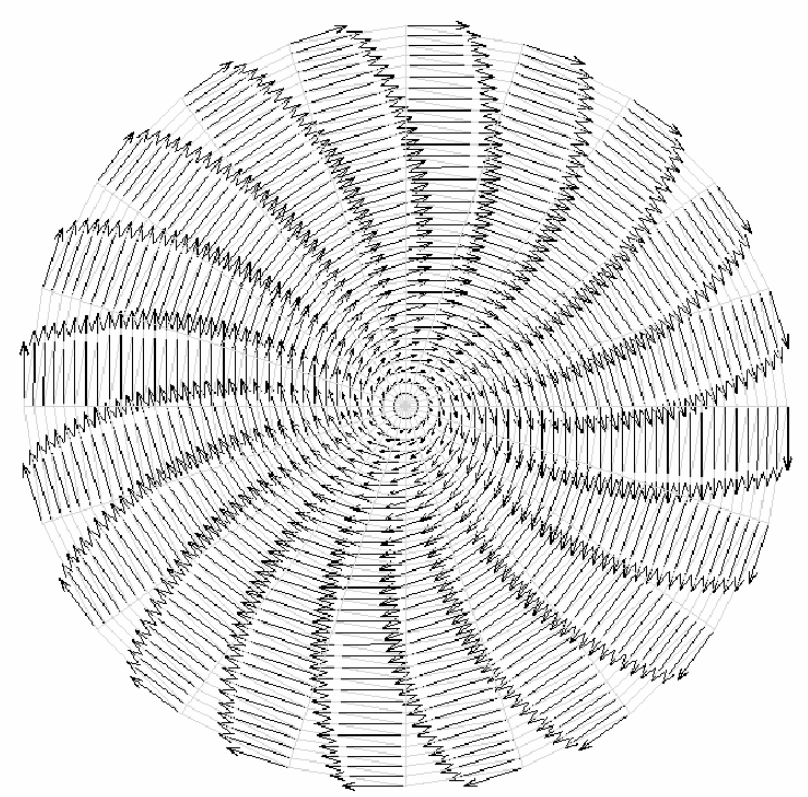

Fig. 3. Initial swirl profile assumed for modelled engine $(\alpha=2.7)$ Rys. 3. Profil wstepnego zawirowania przyjety dla modelowanego silnika $(\alpha=2,7)$

The velocity swirl profile described in KIVA-3V by $\alpha=3.11$ parameter was chosen by Wahiduzzaman and Ferguson as the one, which is universal and can be applied in typical engine applications.

Figure 3 shows the shape of initial swirl profile of modelled engine. It was determined on the basis of the experimental researches.

Figure 4 shows the variations of swirl factor for modelled cylinder. The maximum rotation speed of compressed charge occurs before TDC.

\section{Modelling of engine thermal cycle}

Thermal cycle of S320 SI test engine has been performed within the confines of numerical modelling in KIVA-3V. 3D cylinder model was designed and boundary initial conditions were defined, as well. traktowany jest jak wirujące ciało sztywne. Założenie to w rzeczywistości jest niemożliwe do spełnienia, ponieważ turbulentna warstwa przyścienna tworząca się przy ściance cylindra wymusza zmiany w profilu zawirowania. Oddziaływanie warstwy przyściennej powoduje zmniejszenie prędkości wiru w pobliżu ścianki.

W modelu tym przyjmuje się, że po zakończeniu napełniania ładunek cylindra wiruje jako nieodkształcalne ciało sztywne (walec) o średnicy D równiej średnicy cylindra i masie $\mathrm{m}$.

Inne podejście w opisie wstępnego zawirowania jest przedstawione w modelu CONCHAS [1], gdzie przyjęto trapezowy profil prędkości zawirowania. Model ten charakteryzuje się założeniem zerowych prędkości w osi cylindra oraz na ściance cylindra. Jest on rozwinięciem modelu opisującego zawirowanie jako ruch wirowy ciała sztywnego. Przedstawione dwa modele wstępnego zawirowania ładunku wykorzystano w dwuwymiarowym modelu komory spalania CONCHAS. Model o profilu trapezowym ujmuje już oddziaływanie warstwy przyściennej, chociaż w sposób bardzo uproszczony.

Na podstawie badań eksperymentalnych prowadzonych przez wielu badaczy stwierdzono, że z największą dokładnością jakość przepływu oddaje opis zawirowania funkcją Bessela [1]. Taki opis zastosowano w programie KIVA 3V. Jest to model zawirowania, w którym można w pewnych granicach zmieniać profil zawirowania. Można uzyskać profil prędkości jak dla wirującej bryły sztywnej z maksymalną prędkością na ściance cylindra $(\alpha=0,0)$, profil o kształcie łuku z zerową prędkością na ściance cylindra $(\alpha=3,83)$ oraz profil prędkości o kształcie najbardziej zbliżonym do rzeczywistego wiru $(\alpha=3,11)$.

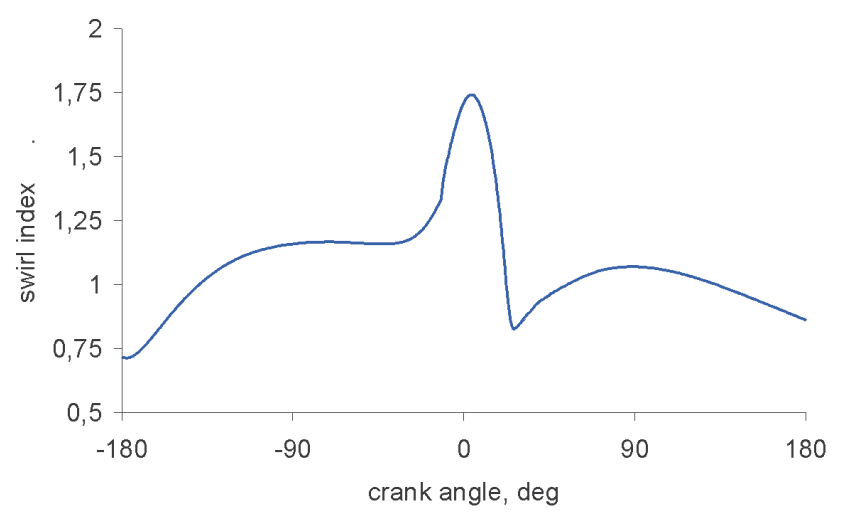

Fig. 4. Variations of swirl factor

Rys. 4. Przebieg zmian wskaźnika zawirowania

Profil prędkości zawirowania opisany w programie KIVA $3 \mathrm{~V}$ parametrem $\alpha=3,11$ został zaproponowany przez Wahiduzzaman i Ferguson [1], jako uniwersalny dla większości typowych zastosowań silnikowych.

Na rysunku 3 przedstawiono kształt profilu wstępnego zawirowania dla modelowanego silnika. Został on określony na podstawie badań eksperymentalnych dla modelowanego silnika.

Na rysunku 4 przedstawiono przebieg zmian wskaźnika zawirowania dla cylindra modelowanego silnika. Z przebie- 

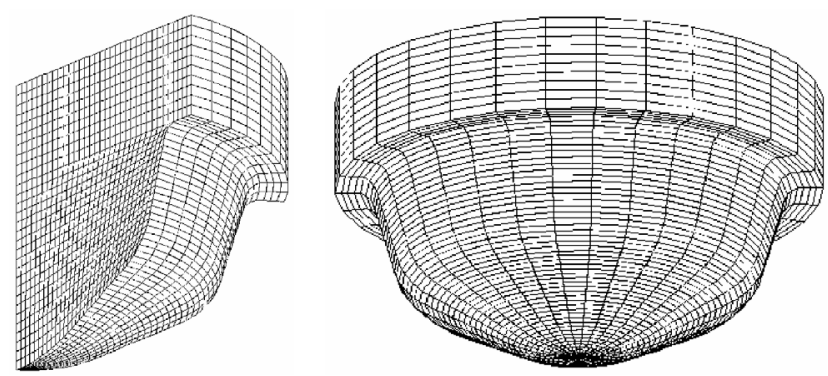

Fig. 5. Engine combustion chamber

Rys. 5. Komora spalania silnika

Figure 5 shows the geometric mesh of modelled engine. Main parameters of the engine are:

compression ratio

cylinder volume

$-$

cylinder bore

inside crank radius

squish

rotational speed

8.5

$1810 \mathrm{~cm}^{3}$,

$120 \mathrm{~mm}$,

$80 \mathrm{~mm}$,

The numerical modelling results of analysed engine are presented as mean parameters for the cylinder volume.

Figure 6 depicts the turbulence kinetic energy and turbulence intensity. These parameters gain their maximal values after TDC, so at the time of flame front development. The modelled engine is a gaseous engine of charge prepared out
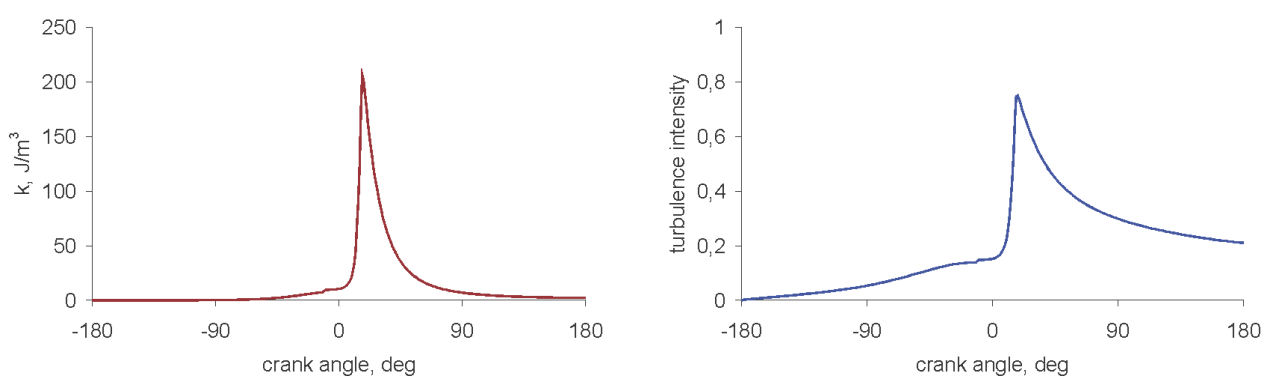

Fig. 6. Turbulence kinetic energy and turbulence intensity Rys. 6. Energia kinetyczna turbulencji oraz intensywność turbulencji tłoka. parametry silnika:

stopień sprężania

objętość skokowa

średnica cylindra

promień wykorbienia

niedojście tłoka

prędkość obrotowa objętości cylindra. gu zmian tego parametru widać, że maksimum prędkości wirowania sprężanego ładunku zachodzi tuż przed ZZP

\section{Modelowanie obiegu cieplnego silnika}

$\mathrm{W}$ ramach modelowania numerycznego programem KIVA $3 \mathrm{~V}$ przeprowadzono modelowanie obiegu cieplnego silnika badawczego S320 ZI. Stworzono trójwymiarowy model cylindra, określono warunki brzegowe i początkowe.

Na rysunku 5 przedstawiono siatkę geometryczną przestrzeni roboczej modelowanego silnika badawczego. Główne

$\begin{array}{ll}- & 8,5 \\ - & 1810 \mathrm{~cm}^{3} \\ - & 120 \mathrm{~mm} \\ - & 80 \mathrm{~mm} \\ - & 2 \mathrm{~mm}\end{array}$
$1000 \mathrm{obr} / \mathrm{min}$

Wyniki modelowania dla badanego silnika przedstawiono w postaci wykresów uśrednionych parametrów dla całej

Na rysunku 6 zilustrowano charakter zmian energii kinetycznej turbulencji oraz intensywności turbulencji. Parametry te osiągają swe maksima po przejściu tłoka przez ZZP, czyli w czasie, kiedy rozwija się front płomienia. Modelowany silnik jest silnikiem gazowym o ładunku przygotowanym poza przestrzenią roboczą, dlatego procesy przepływowe zachodzące w czasie ruchu tłoka w kierunku ZZP mają za zadanie doprowadzić do ujednorodnienia mieszanki.

Na rysunku 7 przedstawiono przebieg zmian ciśnienia $\mathrm{w}$ badanym silniku. Maksymalne ciśnienie osiągnęło wartość na poziomie 4,88 $\mathrm{MPa}$ i występowało dla $18^{\circ} \mathrm{OWK}$ po ZZP tłoka.

Rysunek 8 przedstawia przebieg zmian temperatu-

of the cylinder volume and that is why the flow processes occurring when piston moves towards TDC are to homogenize the mixture.

Pressure course in the analyzed engine is presented in Fig. 7. The maximal pressure gained the value of $4.88 \mathrm{MPa}$ and was obtained at $18 \mathrm{CA}$ after TDC.

Temperature course in the analyzed engine is presented in Fig. 8. The maximal temperature gained the value of $2080 \mathrm{~K}$ and was obtained at $22 \mathrm{CA}$ after TDC.

In the case of engines with fuel injection to the combustion chamber, above mentioned flow processes are even more important as they contribute to mixture distribution in the combustion chamber in relatively short period of time. ry w cylindrze badanego silnika. Maksymalna temperatur występowała dla $22^{\circ} \mathrm{OWK}$ po ZZP tłoka i osiągnęła wartość $2080 \mathrm{~K}$.

Dla silników z wtryskiem paliwa do komory spalania istota tych zjawisk przepływowych jest jeszcze ważniejsza, ponieważ odpowiedzialne są one za rozprowadzenie paliwa w komorze spalania w stosunkowo krótkim czasie.

\section{Podsumowanie}

W artykule przedstawiono zagadnienie modelowania obiegu cieplnego silnika ZI, ze szczególnym uwzględnieniem procesu wstępnego zawirowania. Dla modelowanego silnika parametry opisu wstępnego zawirowania określono na podstawie badań eksperymentalnych, co może stanowić 


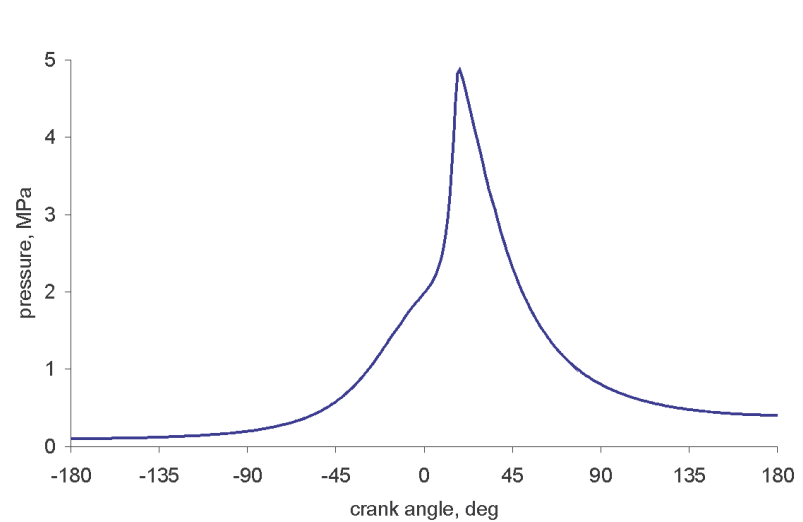

Fig. 7. Course of pressure

Rys. 7. Przebieg zmian ciśnienia

\section{Summary}

The paper presents SI engine thermal cycle modelling with taking initial charge swirl under consideration. Parameters describing the initial charge swirl in modelled engine have been specified on the basis of experimental research, which can be important in the case of numerical modelling results comparison with experimental research results. The proper level of turbulence before the initiation of combustion is very important for engine work as air and fuel mixing occurs at that time. The developing ignition kernel is influenced by charge swirl, which forms its initial shape and the direction of its growth and therefore the charge swirl determines the subsequent course of combustion. The engine thermal cycle modelling proved significant influence of assumed initial swirl profile on the variations of pressure and temperature in the engine cylinder. Not only the initial swirl factor but also the initial shape of swirl velocity profile should be determined in engine models, which do not take the inlet duct into consideration.

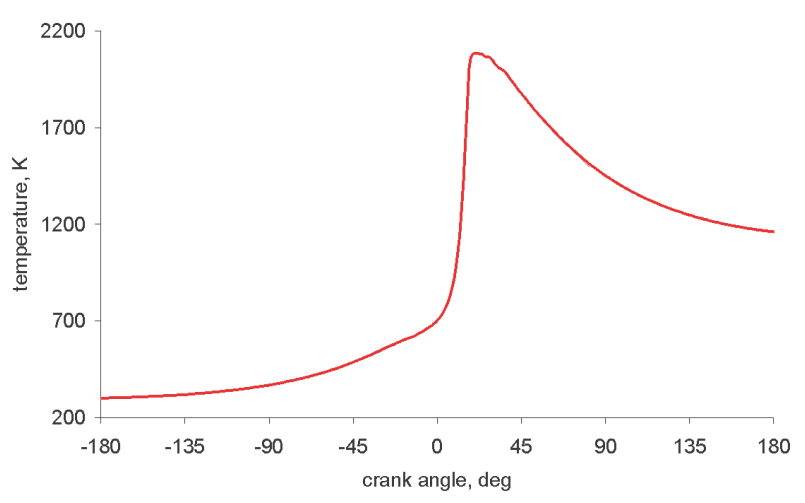

Fig. 8. Course of temperature Rys. 8. Przebieg zmian temperatury

kolejny krok w kierunku przybliżenia wyników modelowania do wyników uzyskanych z eksperymentu.

Dla pracy silnika istotne jest uzyskanie odpowiedniego poziomu turbulencji przed zainicjowaniem procesu spalania, ponieważ w tym czasie następuje mieszanie się paliwa z powietrzem. Tworzące się jądro zapłonu poddane jest oddziaływaniu wirów ładunku, które, kształtując jego początkowy kształt i kierunek rozwoju, decydują o dalszym przebiegu procesu spalania.

Modelowanie obiegu cieplnego silnika wykazało istotny wpływ przyjętego profilu wstępnego zawirowania na przebieg zmian ciśnienia i temperatury w cylindrze silnika.

Przy modelach silnika nieuwzględniających układu dolotowego, należy określić nie tylko wskaźnik wstępnego zawirowania, ale także początkowy kształt jego profilu prędkości.

Artykut recenzowany

\section{Bibliography/Literatura}

[1] Amsden A.A., O’Rourke P.J., Butler T.D.: KIVA-II, A computer program for Chemically Reactive Flows with Sprays. Los Alamos National Laboratory LA-11560-MS (May 1989).

[2] Heywood J. B.: Fluid motion within the cylinder of internal combustion engines - The 1986 Freeman Scholar Lecture. ASME Journal of Fluids Engineering, vol. 109, No. 3.

[3] Heywood J.B.: Internal combustion engine fundamentals. McGraw - Hill Book Company. 1988.

[4] Patterson D. J.: Cylinder pressure variations, a fundamental combustion problem. SAE, 1966 No.660129.

[5] Tutak W., Jamrozik A., Kociszewski A., Sosnowski M.: Numerical analysis of initial swirl profile influence on modelled piston engine work cycle parameters. Silniki Spalinowe/Combustion Engines, Mixture Formation Ignition \& Combustion, 2007-SC2, 2007.

[6] Cupiał K., Sosnowski M., Jamrozik A., Kociszewski A., Tutak W.: Flame kernel formation around a spark plug of SI engine using KIVA-3V with standard and newly developed ignition model. SILNIKI SPALINOWE/Combustion Engines, Mixture Formation Ignition \& Combustion, 2007-SC2, 2007.
[7] Tutak W., Jamrozik A., Kociszewski A., Sosnowski M., Experimental Research into Turbulence Field in Combustion Chamber of Internal Combustion Engine, Journal of KONES Powertrain and Transport, Vol 13, No 2, European Science Society of Powertrain and Transport Publication, Warsaw 2006.

[8] Whitelaw J.H., Xu H.M.: Cyclic variations in a lean-burn spark ignition engine without and with swirl. SAE, 1995, No. 950683.

Mr Wojciech Tutak, PhD, MEng - doctor in the Faculty of Mechanical Engineering and Computer Science of Czestochowa University of Technology. Dr inż. Wojciech Tutak - adiunkt na Wydziale Inżynierii Mechanicznej i Informatyki Politechniki Częstochowskiej. 